\title{
Learning to be Jewish
}

Eli Gottlieb

\begin{abstract}
Tewish education is, among other things, a form of religious education. But what does it mean to learn religion, or to learn a particular religion? We can learn facts about a particular religion or theories about religions in general-but that seems more like social studies, history, or the study of comparative religion. In this chapter, Gottlieb addresses three aspects of this question. First, he focuses on children's religious thinking, reporting on his discovery that the existing theories about developmental stages fit poorly with the Israeli Jewish children that he studies. In some instances, and on some topics, these children exhibit more sophistication in their religious thinking than the theories would have predicted. He then turns to examining more closely the affects of different schools on their students' religious thinking. Whereas the psychological literature tends to assume that religious thinking is a function of psychological development, he documents that, in fact, "these ways of believing are embedded in distinctive ways of talking about belief that are characteristic of particular Jewish-Israeli communities." Finally, Gottlieb describes his study of the "epistemic switching" that occurs even among sophisticated readers, as they move between academic and religious modes in understanding and talking about religious texts. This observation raises intriguing questions about precisely what learning outcomes we aspire for our students to achieve.
\end{abstract}

Meet Sophie. Sophie is an eighth-grader in a North American Jewish day school. It's Tuesday morning, 10:55 a.m. Sophie sits quietly, two rows from the front, second desk to the right, half-listening to Rabbi David review the material from last week's class, half-watching a fly buzzing in and out of the open window. In Sophie's schedule, the class appears as "Jewish Studies." It comes after Mathematics and before English. What does Sophie do in this class that is different from what she does in the classes before and after it? What, if anything, does Rabbi David (or the principal or the board of governors or Sophie's parents) want to be different?

Sophie, her desk, her schedule, Rabbi David, and the fly are all figments of my imagination. But the scene is familiar. In some day schools, Sophie would 
be Devorah, Jenny, or Stav. Rabbi David might be Rabbi Sarah or Dr. Jacobson or Ha-Morah Avital. Instead of "Jewish Studies," it might be "Judaic Studies" or "Limmudei Kodesh" or, less generically, "Tanakh" or "Machshevet." The question, however, remains the same: Mah nishtanah hakitah hazo mikol hakitot? How is this class different from all other classes? And how ought it to be different?

I am tempted to answer that in other classes the goal is for Sophie to know particular things, whereas in this class the goal is for Sophie to become a particular kind of person. Immediately, however, this distinction begins to look like an overstatement, if not an outright false dichotomy. Researchers have been aware that knowing and being are intertwined since at least as far back as the 1990s, when the study of cognition took a cultural turn, ${ }^{1}$ if not a good deal earlier, when L. S. Vygotsky ${ }^{2}$ first suggested that all higher-order thinking is social. Indeed, some of the most interesting research in the learning sciences in recent years has been about the ways that knowing and being are connected. Researchers like Donna LeCourt, ${ }^{3}$ Stanton Wortham, ${ }^{4}$ and Paul Cobb and colleagues, ${ }^{5}$ for example, have shown how students become particular kinds of person while learning school subjects like literature or mathematics.

Nevertheless, learning to be Jewish does seem to be different. As conventionally conceived, the educator's primary goals in teaching secular school subjects like mathematics and English are to increase learners' knowledge and practical competence. That students' identities are entangled in this process is a significant by-product that researchers and theorists, like those cited above, ask us to acknowledge and to address responsibly. In Jewish education, however, the priorities are reversed. The acquisition of knowledge is a by-product or a necessary precondition. But the ultimate goal is to encourage learners to

1 For example, Jerome Bruner, The Culture of Education (Cambridge, MA: Harvard University Press, 1996); Michael Cole, Cultural Psychology: A Once and Future Discipline (Cambridge, MA: Harvard University Press, 1998); Barbara Rogoff, Apprenticeship in Thinking: Cognitive Development in Social Context (Oxford: Oxford University Press, 1990).

2 L. S. Vygotsky, Mind and Society: The Development of Higher Mental Processes (Cambridge, MA: Harvard University Press, 1978).

3 Donna LeCourt, Identity Matters: Schooling the Student Body in Academic Discourse (New York: SUNY Press, 2004).

4 Stanton Wortham, Learning Identity: The Joint Emergence of Social Identification and Academic Learning (Cambridge: Cambridge University Press, 2006).

5 Paul Cobb et al., "An Interpretive Scheme for Analyzing the Identities that Students Develop in Mathematics Classrooms," Journal for Research in Mathematics Education 40, no. 1 (2009), $40-68$. 
be particular kinds of person. Learning to be Jewish is the focus of the entire enterprise. Learning the laws of kashrut or what to do in a synagogue or how to read a page of Talmud are a means to this end. Abraham Joshua Heschel ${ }^{6}$ makes a similar point:

It is not only important what a person does; it is equally and even more important what a person is. Spiritually speaking, what he does is a minimum of what he is. Deeds are outpourings, they are not the essence of the self. Deeds reflect or refine but they remain functions. They are not the substance of the inner life. Hence it is the inner life that is the problem for us, Jewish educators, and particularly the inner life of the Jewish child.

My research over the last two decades has sought to characterize more precisely the ways in which learning to be Jewish differs from other kinds of learning. In this chapter, I focus on three kinds of difference: differences in content, differences in context, and differences in goals. The order in which I discuss these three differences is not accidental. It recapitulates my own professional journey as an educational practitioner and cognitive psychologist. I began by studying differences in how children think about religious and non-religious content. I then investigated how the development of these differences varies across cultural contexts. Finally, and most recently, I have studied models of mature religious thinking that Jewish education might seek to cultivate.

What each of these phases of my research have in common is their empirical focus. My research examines what people do-not what they say they do or what someone else thinks they ought to do. ${ }^{7}$ Herein, I believe, lies its value to Jewish educators. To the extent that my findings are credible, they provide us with the beginnings of an empirical foundation on which to base instructional design, one that takes into account how Jewish education is different to other kinds of education.

\section{Different Contents}

It is surprising how little thought we give to theology in contemporary Jewish education. It is true that, compared with other Western religions, Judaism is

6 Abraham Joshua Heschel, "The Spirit of Jewish Education," Journal of Jewish Education 24, no. 2 (1953), 16.

7 Eli Gottlieb, "On the Corruption of Jewish Education by Philosophy," in Educational Deliberations: Studies in Education Dedicated to Shlomo (Seymour) Fox, ed. Mordecai Nisan and Oded Schremer (Jerusalem: Keter, 2005), 404-29. 
more practice-oriented than belief-oriented. Indeed, only five out the $613 \mathrm{com}$ mandments in Maimonides' Sefer Hamitzvot refer to things that we are commanded to believe. Nevertheless, belief is far from irrelevant to Jewish life and practice. For example, belief in one God-as opposed to none or many-was for much of Jewish history a necessary condition for participation in Jewish community. As Baruch Spinoza and others learned the hard way, transgress that one and you were out. ${ }^{8}$

In educational practice, however, belief in God tends to feature as an unexamined background assumption. In educational theory and research, it is generally ignored. As a result, our knowledge about Jewish children's religious beliefs, and our articulation of the goals of Jewish education in relation to such beliefs, is partial and informal, to say the least.

Several years ago, I embarked on a program of empirical research aimed at understanding how children's religious thinking develops. Initially, my interest in these questions was practical. As a Jewish educator, I noticed that my colleagues and I were working on the basis of all kinds of assumptions about what children can and cannot understand at different ages. Based on these assumptions, we derived all sorts of practical rules of thumb about which issues to raise when. But I began to wonder whether these assumptions were justified. Perhaps children were more sophisticated than we assumed. I presumed that this kind of thing had been thoroughly studied by cognitive and developmental psychologists and that all I needed to do was to read the relevant literature and derive the appropriate practical conclusions.

As I began to acquaint myself with the existing research, however, I realized that my expectations were misplaced. First, very few studies had been conducted in this area. Second, those that had been conducted were generally not very rigorous, and I therefore needed to take their conclusions with a pinch or two of salt. Third, studies differed substantially in their conceptual frameworks, methods, and conclusions, making it difficult to determine the overall implications of their findings for educational practice. ${ }^{9}$

My most troubling discovery, however, was the extent to which the existing research on children's religious thinking rested on broadly Protestant

8 Asa Kasher and Shlomo Biderman, "Why Was Baruch de Spinoza Excommunicated?, in Spinoza: Context, Sources, and the Early Writings, ed. Genevieve Lloyd (London: Taylor \& Francis, 2001); Yirmiyahu Yovel, Spinoza and Other Heretics: The Marrano of Reason (Princeton, NJ: Princeton University Press, 1991).

9 See Eli Gottlieb, "Development of Religious Thinking," Religious Education 101, no. 2 (2006), 242-60. 
conceptions of mature faith. Interestingly, this was true even of studies conducted by Jews. ${ }^{10}$ The reasons for this theological bias are unclear. I suspect that it has something to do with the fact that many of the studies were conducted in the United States and countries in Western Europe where Protestantism is deeply ingrained in the culture. I also suspect that it has something-perhaps even more - to do with the influence of Jean Piaget on developmental psychology. The tendency to view abstract thought as by definition more advanced than concrete thought is one that, applied to religious thinking, can have the unintended effect of classifying characteristically Protestant tendencies (e.g., valuing faith over deeds; interpreting religious language as allegorical) as more mature or sophisticated than tendencies characteristic of other faith traditions.

In short, my search for off-the-shelf answers to my practical questions ended in disappointment. Rigorous and relevant research was scarce and the assumptions that Jewish educators were making about children's religious thinking lacked empirical support. I realized that if reliable empirical data about the religious thinking of Jewish children and adolescents wasn't available off the shelf, I should collect it myself.

And that is what I did. Over a number of years, I conducted empirical studies that compared how children think about religious and non-religious content. ${ }^{11}$ My initial research examined within-subject differences with respect to analogical reasoning, that is, differences that appear in data gathered from the same person engaged in two different domains. I compared the scores of a sample of British elementary school children on a battery of written reasoning tasks. Some of the items were excerpted from intelligence tests and contained no religious content; other items were excerpted from Ronald Goldman's ${ }^{12}$ test of religious thinking. Contrary to the claims of previous studies, ${ }^{13}$ I found no significant correlation

10 For example, David Elkind, "The Child's Conception of His Religious Domination: (1) The Jewish Child," Journal of Genetic Psychology 99, no. 2 (1961), 209-25; David Elkind, "The Child's Conception of His Religious Domination: (2) The Catholic Child," Journal of Genetic Psychology 101, no. 1 (1962), 185-93; David Elkind, "The Child's Conception of His Religious Domination: (3) The Protestant Child," Journal of Genetic Psychology 103, no. 2 (1963), 291-304.

11 Eli Gottlieb, “The Role of Analogical Reasoning in the Development of Religious Thinking” (master's thesis, Cambridge University, 1994); Eli Gottlieb, "Religious Thinking in Childhood and Adolescence: Argumentative Reasoning and the Justification of Religious Belief" (PhD thesis, Hebrew University of Jerusalem, 2002).

12 Ronald Goldman, "Religious Thinking from Childhood to Adolescence" (London: Routledge and Kegan Paul, 1964).

13 For example, James W. Fowler, Stages of Faith: The Psychology of Human Development and the Quest for Meaning (San Francisco, CA: Harper and Row, 1981); Goldman, "Religious 
between children's understanding of Biblical texts and their general ability to reason by analogy. Indeed, contrary to Goldman's claim that children who cannot reason analogically are incapable of mature religious thinking, my study found that children's ability to reason analogically was neither a necessary nor a sufficient condition for mature religious thinking, as measured by Goldman's own test!

Next, I investigated how religious thinking develops among Jewish-Israeli children and adolescents. The study included individual, semi-structured interviews with two hundred fifth, eighth, and twelfth graders about two controversies (i.e., situations in which interviewees are asked to imagine two interlocutors arguing about a contentious topic) ${ }^{14}$ _one about belief in God and the other about punishment of children. My sample was stratified by age, gender, and school type. ${ }^{15}$ The interviews took place, for the most part, on school premises, so I spent time in both state (secular) schools and statereligious (modern orthodox) schools in Israel's largest school district.

Prior to analyzing the data, and based on the claims of previous research into children's religious thinking, ${ }^{16}$ I predicted that the interviewees' thinking about the religious controversy would lag behind their thinking about the non-religious controversy, since these earlier studies indicated that religious thinking involves cognitive abilities that are sophisticated and late-developing. What I found was almost exactly the opposite. Sophisticated forms of argumentation previously associated with late adolescence and early adulthood appeared earlier in the religious controversy than the non-religious controversy. In other words, children exhibited sophisticated reasoning in relation to religious content at younger ages than they did with respect to non-religious content.

To sum up this first phase of my research, I found that the picture painted by earlier studies of children's religious thinking needed redrawing. Instructional design in Jewish education based on early studies of religious thinking rested on shaky empirical foundations. Yet, at the same time, differences between the pace and direction of cognitive development in the religious domain versus other domains were sufficiently well-documented to give us pause before

Thinking”; Fritz Oser and Paul Gmünder, Religious Judgment: A Developmental Perspective (Birmingham, AL: Religious Education Press, 1991).

14 Anne Colby and Lawrence Kohlber, The Measurement of Moral Judgment: Theoretical Foundations and Research Validation (New York: Cambridge University Press, 1987).

15 See Eli Gottlieb, "Religious Thinking in Childhood and Adolescence"; Eli Gottlieb, "Learning How to Believe: Epistemic Development in Cultural Context," Journal of the Learning Sciences 16, no. 1 (2007), 5-35.

16 For example, Fowler, Stages of Faith; Goldman, "Religious Thinking”; Oser and Gmünder, Religious Judgment. 
basing our instructional designs on generic assumptions about children's cognitive development. We needed more specific and detailed research.

\section{Different Contexts}

In addition to the differences that I found between how individuals reasoned about religious and non-religious content, my study also yielded intriguing findings related to context, namely, differences between schools. Most notably, over two-thirds of pupils in state schools considered their belief in God to be fallible (i.e., they were willing to entertain the possibility that their belief in God might be mistaken), compared with less than a third of pupils in state-religious schools. This difference was preserved even when removing non-believers from the analysis (thirty-seven out of the two hundred participants, or about 19 percent of the sample), or when controlling for age and family religiosity. In other words, even when subscribing to ostensibly the same belief, participants from state-religious schools believed it "differently" to their peers at state schools. Specifically, whereas state-religious pupils considered belief in God to be something akin to a demonstrable and incontrovertible fact, state pupils considered it to be more like an opinion or a personal preference.

To understand better these differences and their possible sources, I attended very carefully to how participants in the study described the kinds of theological discourse they encountered at school. In state-religious schools, pupils reported encountering theological discourse within the context of official classes in which teachers or rabbis set out to prove God's existence and to rebut conclusively any potential counterarguments. As Hannah, a statereligious eighth-grader, commented, "Every seminar they bring up the whole thing; that God exists, proving to us that God exists."

In contrast, when pupils in state schools referred to previous occasions on which they had discussed the question of God's existence, they tended to cite informal conversations with peers that ended with the opposing sides agreeing to disagree. The following comment by Ron, a state twelfth-grader, is typical: "To tell you the truth, I had exactly the same argument with my friend. We sometimes go hiking and speak about this kind of stuff. And I didn't succeed. I'm always saying stuff to him and he's always saying stuff to me, but neither of us is ever persuaded."

Further insight into these differences was provided by two instances of "pre-interview coaching" at two of the state-religious elementary schools in 
which I conducted interviews. ${ }^{17}$ In each of these schools, my suspicions of prior coaching were first aroused after encountering almost identical lines of argumentation in my interviews with pupils from one particular class. These suspicions were later confirmed by pupils' explicit admissions later in the interview that they had indeed been "prepared" for my visit. In one school, pupils had been told a story about Rabbi Akiva (though in one version, Akiva had mutated into Maimonides), who convinces a skeptic (in some versions a gentile, in others a heretic) by showing him a beautiful painting and telling him that his cat (in almost all versions: "Mitzi") had painted it by accident by upsetting a box of paints on a canvas. When the skeptic objects that a cat could not have produced such a magnificent work of art, the rabbi points out the much greater complexity and beauty of the natural world, showing that it too must be the result of design. In the second school, pupils were told a story about a school inspector who challenges the pupils by insisting that, since he can't see God, He must not exist. One of the pupils in the story then responds that the inspector must have no intelligence, since he can't see that either. ${ }^{18}$

These snippets of unsought evidence provide an intriguing glimpse of how the discourse to which children and adolescents are exposed in school relates not only to what they believe, but to how they believe. By exposing pupils to models of theological discourse in which all questions can be answered clearly and conclusively in the affirmative, state-religious schools appear to foster an absolutist religious epistemology, within which believers are so confident in the truth of their position that they consider it effectively infallible. Conversely, by

17 See Eli Gottlieb, "Arguments as Venues for Cultural Education: A Comparison of Epistemic Practices at General and Religious Schools in Israel," in Cultural Education-Cultural Sustainability, ed. Zvi Bekerman and Ezra Kopelowitz (Mahwah, NJ: Erlbaum, 2008), 404-29.

18 My initial reaction to discovering these instances of coaching was to consider excluding the transcripts from the study, due to their being "contaminated" by the explicit instruction that preceded the interview. However, on reflection, I realized that this would be a mistake, for at least three reasons. First, it would exclude precisely those data most pertinent to my research questions. It would be paradoxical indeed to exclude data from a study of the effects of cultural practices on the grounds that they were "contaminated" by cultural practices. Second, it would distinguish arbitrarily between instances of prior instruction of which I was aware and those of which I was not. Each participant entered the interview with his or her own unique epistemological baggage, accumulated over the course of his or her entire life prior to that moment, and from an indefinite variety of sources. Who is to say, and on what grounds, which of that person's epistemological statements were "real" and which "merely parroted"? Third, viewing these instances as "contaminated" makes sense only if one assumes that "genuine" epistemological beliefs are things that one constructs in one's head without outside assistance. 
implicitly consigning religious beliefs to the private domain, state schools seem to promote a view of theological matters as questions of personal preference that lie beyond the pale of rational debate.

These between-school differences are striking enough in their own right. They are even more striking when considered in comparative context. In addition to asking each of the two hundred participants a series of questions about his or her belief in God, I asked them a parallel series of questions about their beliefs regarding a non-religious belief, namely, whether or not children should be punished when they misbehave. My analyses of their responses to this latter series of questions indicated no significant between-school differences whatsoever. This suggests that the differences observed in relation to belief in God were not due to some general difference in epistemological practices in state-religious schools versus state schools, but rather to divergent practices with respect to religious belief in particular.

When I first published these findings, my intended audience was learning scientists. The ideas I wanted to emphasize were that not all learning is the same; that children and adolescents learn to treat religious beliefs differently to how they treat other kinds of belief; and that the nature and extent of these differences is affected by the kinds of discourse to which they are exposed in school. However, I believe the study has implications for Jewish education that are both more general and more specific.

The study showed that state-religious and state pupils had different ways of believing. But it showed something else too. These ways of believing are embedded in distinctive ways of talking about belief that are characteristic of particular Jewish-Israeli communities. To be a contemporary secular Jew in Israel is, among other things, to talk about belief in God as if it were a private matter of personal preference. Similarly, to be a contemporary religious Jew in Israel is, among other things, to talk about belief in God as if it were a public matter of provable fact. There are of course exceptions and variations to these patterns. But these are the patterns. In both state-religious and state schools, pupils are learning to be Jews of particular kinds.

Though, as I noted at the start of this chapter, there is a good deal more to Jewishness than theology, God is still a pretty prominent character in many Jewish texts and traditions. If pupils in state-religious and state schools understand God-talk differently to one another, then the ways they interpret Jewish texts, ideas, and traditions may also diverge in significant ways. In other words, even when studying the same texts as one another, pupils at statereligious and state schools may be engaged in encounters of quite different 
kinds with the material. The implications of these differences have yet to be comprehensively addressed by educators.

\section{Different Goals}

No Jew today lives within just one community. We all participate in multiple communities. I am not talking only about the expanding number of groups to which each of us subscribes on WhatsApp or Twitter. I mean the different social, professional, ideological, and recreational groupings through and around which we organize our lives. I don't know if any human has ever lived his life entirely within a single community. Perhaps. But even in eras when tribes, castes, religious orders, and professional guilds provided more rigid boundaries, I suspect that crossing, mixing, and switching between groups was the norm rather than the exception. Today, the number of groups in which an average Jew participates, and the rate at which this number is increasing, is probably higher than ever before in history. From the yeshiva bocher in Bnei Brak checking the NBA results on his iPhone to the secular kibbutz retiree posting a comment on YNET's parshat ha-shavua page-each of us moves between communities, sometimes without blinking, often without thinking, several times per day.

(It is worth noting - for now, parenthetically and midrashically - that the idea of boundary-crossing and belonging to more than one place or community has been at the heart of the Jewish experience since antiquity. The term, "Hebrews," means, quite literally, "those who cross over." Jews have wandered, and been defined by wandering, throughout history-from the wilderness of Sinai to the mass migrations of the nineteenth century.)

One of the many challenges this poses for Jewish education is that of defining goals in relation to multiplicity. Toward what kind of a person do we wish to educate? Is the ideal graduate of a Jewish education someone who prioritizes participation in Jewish community over participation in other communities? Is it someone who crosses or alternates between communities in a particular way?

These rather abstract questions have very practical corollaries. For the present purposes, I will focus on one that relates specifically to reading Jewish texts. This focus is not arbitrary, but neither should it be taken for granted. I appreciate that there are ways of participating in Jewish community that are text-lite. The Maccabiah athlete, J-Date user, and nostalgic bagel eater are all participants in recognizable forms of Jewish community. The "people of the book" are not defined by books alone. Nevertheless, Judaism is a profoundly textual tradition. 
Scholars and practitioners of Jewish education (of each and every stripe) have given much thought to general questions about how to teach Jewish texts, and how to combine Jewish and secular school subjects in day schools. However, we have devoted little attention to characterizing how, ultimately, we would like graduates of a good Jewish education to read. We know more about what we don't want than what we do want. We don't want our graduates to read Jewish texts in ways that are either uncritically loyal or disloyally critical. On one hand, we want them to read in ways that show the texts are theirs; that the texts belong to them and they to the text. On the other hand, we want them to read in ways that take into account other perspectives; that are awake and alive to criticisms and alternatives and modern challenges. We lack not only a clear characterization of what such reading looks like but also of the kinds of learning that are likely to lead students to read this way.

One thing that might help here is to collect and study exemplars of expert performance. Just as researchers have studied how expert chess players and historians read chessboards and historical documents, ${ }^{19}$ so might we study expert readers of Jewish texts to understand better what it means to "read like an educated Jew."

In a recent study, ${ }^{20}$ Sam Wineburg and I collected and analyzed several such exemplars. This was not the initial goal of our research. When we began the study, we wanted more generally to examine how people's religious commitments and historical expertise influence their readings of historical texts. We compared how eight religious believers (historians and clergy) and eight skeptics (historians and scientists) read a series of documents on two topics: the Biblical Exodus and the origins of the First (American) Thanksgiving. We found that readings by religiously committed historians differed from those of their non-religious peers. Navigating between the competing commitments of their faith communities on one hand, and an academic guild on the other, religious historians engaged in epistemic switching, varying epistemological criteria to align with the allegiances triggered by the document under review. To explain these findings, we proposed that historical understanding be conceived not as a unitary

19 William G. Chase and K. Anders Ericsson, "Exceptional Memory," American Scientist 70, no. 6 (1982), 607-15; Sam Wineburg, "Reading Abraham Lincoln: An Expert/Expert Study in the Interpretation of Historical Texts," Cognitive Science 22, no. 3 (1998), 319-46.

20 Eli Gottlieb and Sam Wineburg, "Between Veritas and Communitas: Epistemic Switching in the Reading of Academic and Sacred History," Journal of the Learning Sciences 21, no. 1 (2012), 84-129. 
construct, but as a form of coordination between multiple axes: a vertical axis of increasing intellectual sophistication as defined by the discipline; and a horizontal axis of identification and commitment, along which individuals move between a variety of allegiances and affiliations as they engage the epistemological criteria of sacred history.

Only a few of the participants in our study were Jewish. Most of the religious participants identified themselves as Christians. However, the ways in which religiously committed historians-from whichever traditioncombined and alternated between different ways of reading provide (in our view) fascinating insights into how readings of religiously significant texts can be both loyal and critical.

The religiously committed historians in our study felt the competing pulls of their professional guild, on one hand, and the religious communities with which they affiliated, on the other. These dual commitments sometimes led to visible tensions. We coined the term epistemic switching to describe how participants dealt with the multiple memberships evoked by these texts. This term denotes a participant's use of multiple frameworks of epistemological assumptions (e.g., historical, theological, scientific) for interpreting documentary evidence. Some employed multiple epistemologies serially; others employed them simultaneously. Some granted equal weight to distinct epistemologies; others privileged one epistemology over another.

One of our interviewees, Professor C, was a religiously observant Jewish professor of history at a public university in the Pacific Northwest. When we asked him which Exodus document best represented his own views, he looked puzzled and asked, "On what day of the week? When I'm teaching my class or when I'm in the synagogue?” He elaborated:

When I'm teaching my courses I'm bound by the rules of historical research and I have an obligation to explain to my students what the tradition of historical scholarship has to say about this material .... Now when I'm in a synagogue, I'm not going to be talking about the historical evidence of the Exodus, I'm going to be doing pretty much actually what the guy I laughed at [in Document 7, at an opinion expressed about the contemporary relevance of the Exodus in an article from the LA Times] does_contemporizing, metaphorizing, allegorizing_because essentially my task there is to make the traditional come alive and address people where they live. To do that, as I said, the historical veracity of the business is hardly relevant at all. 
Relevant exemplars in our study include not only religious historians but also members of the clergy. Rabbi K taught Talmud at a local Jewish high school. He had studied for many years at elite yeshivot in Britain and Israel, but had not attended college. Like Professor C, Rabbi K switched between religious and historical epistemologies. But whereas Professor $\mathrm{C}$ granted each of these epistemologies equal weight, Rabbi $\mathrm{K}$ maintained a clear hierarchy. Rabbi K's antipathy for critical history blazed from the first sentence of Israel Finkelstein and Neil Asher Silberman's The Bible Unearthed ${ }^{21}$ (Document 5 in our Exodus set): "This person has a problem with religion and that's why he's saying this." To the archeologists' claim that the Israelites are nowhere to be found in Egyptian court records, Rabbi K shot back, "Why should they be? The Egyptians were massacred."

This comment is puzzling. The Hebrew Bible makes no mention of wholesale destruction of the Egyptian monarchy, only the crushing defeat of the brigades that tried to overtake the Hebrews (Exodus 15: 1-18). Rabbi K's comment, as well as others he fired off in rapid succession-that Egyptian bondage lasted 210 years instead of the Bible's reckoning of 400, that the Hebrews enjoyed a bountiful water supply during their wanderings, that the manna was so pure that it was digested whole-comes not from the Biblical account but are drawn instead from over two thousand years of rabbinic commentary. Indeed, Rabbi K's protocol on Document 5 was the most densely contextual reading in our entire data corpus, with fourteen separate intertextual references, or one per every eighteen words of the text reviewed. Yet none of these references, each claiming authority to an unbroken oral tradition delivered to Moses at Sinai along with the Ten Commandments, would be considered legitimate sources for establishing the Exodus as a documentable historical event.

Based on his ahistorical approach thus far, we might have assumed that Rabbi K would reject the archeologists' assertions wholesale. It is precisely this expectation that makes his final comments on Document 5 so intriguing. As he reads the excerpt, he begins to wonder what happened to the bones of the Israelites who perished in the desert:

I wonder what [the archeologists] would expect to be there, for a nation that was only there for a short amount of time.... The longest place that they camped in was a year.... Maybe there are places where they stayed

21 Israel Finkelstein and Neil Asher Silberman, The Bible Unearthed: Archeology's New Vision of Ancient Israel and the Origin of Its Sacred Texts (New York: Free Press, 2001), 59-63. 
for more than a year. Even still. Now, they did bury their dead in the wilderness. So I suppose there should be . . . some bones. But I wonder if they didn't look and didn't find any bones of people. That's a good point. There should be bones there. That's interesting. There are no bones there. Interesting. I don't know.

This transcription only approximates the puzzlement in Rabbi K's voice, his fits and starts as he paused with genuine uncertainty, a stance quite different from his earlier dismissal of Silberman and Finkelstein as heretics with an axe to grind. Confronted in the next document with the apologetics of Rabbi David Gottlieb, ${ }^{22}$ who asserts that one must adopt the Biblical account as whole cloth rather than picking and choosing among its threads, Rabbi K refused to abate:

You have to also look for bodies.... The Gemara [Talmud] does say that they went out and dug their own graves... so there was definitely a period of time when people were dying in the wilderness. I wonder what they did with those bodies. It doesn't necessarily say they buried them there. Maybe they took those bodies back to Israel, in which case that would explain why there's no bodies. Or maybe they just haven't looked for bodies. Or maybe they did find bodies, but didn't think that was such a tremendous thing, finding dead bodies in a desert, because you'd expect to find dead bodies in a desert. Okay. Okay. Okay, but I think that's a good point.

The "good point" that stumps Rabbi $\mathrm{K}$ is the nagging question of why no bones have been found. Never does he question the Torah's account, a fact that reflects his unwavering commitment to revelation. However, as he wrestles with the question of the bones, steadily working through possibilities and laying out options, he seems less the theologian falling back on stock answers from the rabbinic tradition than a genuine historical inquirer, critically reasoning about hypotheses, thinking about evidence, and resisting premature closure.

Whether we prefer Professor C's approach to Rabbi K's, or vice versa, each of them provides a model of educated reading that it is worth considering in our efforts to formulate goals for Jewish education. And these are just two of the models we encountered in our study. I am confident that additional studies, with different kinds of readers and different kinds of text, would reveal additional

22 David Gottlieb, Living Up to the Truth, $2^{\text {nd }}$ rev. ed. (Jerusalem: Ohr Sameach International, 1997). 
models we have not yet considered. As has been done in the field of history, ${ }^{23}$ curriculum designers could draw on such analyses to develop curricula and assessments that focus explicitly on teaching students to read in the desired ways.

At the very least, data of the kinds we collected provide a concrete background against which to define educational goals. We might ask ourselves, for example, whether the strategies our readers used to coordinate epistemologies are ones that we would like to see emulated by students in Jewish day schools. If not, what alternative strategies for addressing multiplicity do we want to promote in their place? If epistemic switching and navigation between multiple commitments are indeed features of real-life engagement with sacred texts, then what are the responsibilities of Jewish educators in preparing students to think critically on one hand, without frustrating possibilities for belonging and participation on the other?

\section{Sophie's World}

What does all this have to do with Sophie and her Jewish Studies class? What do these studies teach us about differences between the learning she does in this class and the learning she does in other classes? And what practical difference does any of this make to what Sophie's teachers do or ought to do?

Unfortunately for those who seek simple solutions, these studies raise more questions than they answer. They do not provide us with a cheat sheet of ages and stages of religious thinking, which educators can use as a basis for curricular design. Nor do they provide us with easy generalizations about differences between religious and non-religious thinking that would allow us to apply our general knowledge of developmental psychology straightforwardly to the particular case of Jewish content.

What they do offer, however, is a set of lenses with which to view learning in Jewish educational contexts, and some empirical beacons by which to steer. Rather than making broad assumptions about what Sophie is capable and incapable of understanding in eighth grade, her teachers might attend more carefully to the kinds of questions she asks. In designing their Jewish Studies

23 See, for example, Joel Breakstone et al., "Beyond the Bubble in History/Social Studies Assessments," Phi Delta Kappan 94, no. 5 (2013), 53-57; Avishag Reisman, "Reading Like a Historian: A Document-Based History Curriculum Intervention in Urban High Schools," Cognition and Instruction 30, no. 1 (2012), 86-112; Sam Wineburg and Abby Reisman, "Disciplinary Literacy in History," Journal of Adolescent \& Adult Literacy 58, no. 8 (2015), 636-39. 
classes, Sophie's teachers might give more thought to the ways in which they would like Sophie and her classmates to talk about Jewish content and how these are similar and different to the ways they would like them to talk in other classes and about other school subjects. Finally, Sophie's teachers might consider the models of educated Jewish practice toward which their instructional efforts are directed. Defining how the ideal graduate of a Jewish education ought to read Jewish texts is just one aspect of this. Perhaps, given the centrality of text to Jewish culture, it is a good place to start. But our work to define goals cannot stop there. In an age in which people increasingly participate in multiple communities simultaneously, decisions about which kinds of "switching" to encourage and discourage are of great moment. Jewish educators cannot afford to bury their heads in the sand and pretend that we live in a simpler age. The question is not, "to switch or not to switch?" Instead, given that we switch, it is "how can we (and our students) learn to switch in ways that balance loyalty and openness?"

These are big questions. They are not of a grain size that Sophie's teachers can answer on their own or in a single classroom. But they set an agenda. Not just of things for Jewish educators to consider in planning and implementing specific interventions, but also for future research and deliberation about how people learn to be Jewish. 


\section{Bibliography}

Breakstone, Joel, Mark Smith, and Sam Wineburg. "Beyond the Bubble in History/Social Studies Assessments." Phi Delta Kappan 94, no. 5 (2013), 53-57.

Bruner, Jerome. The Culture of Education. Cambridge, MA: Harvard University Press, 1996.

Chase, William G., and K. Anders Ericsson. "Exceptional Memory." American Scientist 70, no. 6 (1982), 607-15.

Cobb, Paul, Melissa Gresalfi, and Lynn Liao Hodge. "An Interpretive Scheme for Analyzing the Identities that Students Develop in Mathematics Classrooms." Journal for Research in Mathematics Education 40, no. 1 (2009), 40-68.

Colby, Anne, and Lawrence Kohlber. The Measurement of Moral Judgment: Theoretical Foundations and Research Validation. New York: Cambridge University Press, 1987.

Cole, Michael. Cultural Psychology: A Once and Future Discipline. Cambridge, MA: Harvard University Press, 1998.

Elkind, David. "The Child's Conception of His Religious Domination: (1) The Jewish Child." Journal of Genetic Psychology 99, no. 2 (1961), 209-25.

"The Child's Conception of His Religious Domination: (2) The Catholic Child." Journal of Genetic Psychology 101, no. 1 (1962), 185-93.

"The Child's Conception of His Religious Domination: (3) The Protestant Child." Journal of Genetic Psychology 103, no. 2 (1963), 291-304.

Finkelstein, Israel and Neil Asher Silberman. The Bible Unearthed: Archeology's New Vision of Ancient Israel and the Origin of Its Sacred Texts. New York: Free Press, 2001.

Fowler, James W. Stages of Faith: The Psychology of Human Development and the Quest for Meaning. San Francisco, CA: Harper and Row, 1981.

Goldman, Ronald. Religious Thinking from Childhood to Adolescence. London: Routledge and Kegan Paul, 1964.

Gottlieb, David. Living Up to the Truth. 2nd Revised Edition. Jerusalem: Ohr Sameach International, 1997.

Gottlieb, Eli. "Arguments as Venues for Cultural Education: A Comparison of Epistemic Practices at General and Religious Schools in Israel." In Cultural Education - Cultural Sustainability. Edited by Zvi Bekerman and Ezra Kopelowitz, 404-29. Mahwah, NJ: Erlbaum, 2008.

“Development of Religious Thinking." Religious Education 101, no. 2 (2006), 242-60. 
"Learning How to Believe: Epistemic Development in Cultural Context." Journal of the Learning Sciences 16, no. 1 (2007), 5-35.

" "On the Corruption of Jewish Education by Philosophy." In Educational Deliberations: Studies in Education Dedicated to Shlomo (Seymour) Fox. Edited by Mordecai Nisan and Oded Schremer, 404-29. Jerusalem: Keter, 2005.

"Religious Thinking in Childhood and Adolescence: Argumentation and the Justification of Religious Belief." PhD diss., Hebrew University of Jerusalem, 2002.

"The role of analogical reasoning in the development of religious thinking." Master's thesis, Cambridge University, 1994.

Gottlieb, Eli, and Sam Wineburg. "Between Veritas and Communitas: Epistemic Switching in the Reading of Academic and Sacred History." Journal of the Learning Sciences 21, no. 1 (2012), 84-129.

Heschel, Abraham Joshua. “The Spirit of Jewish Education.” Journal of Jewish Education 24, no. 2 (1953), 9-62.

Kasher, Asa, and Shlomo Biderman. "Why Was Baruch de Spinoza Excommunicated?" In Spinoza: Context, Sources, and the Early Writings. Edited by Genevieve Lloyd. London: Taylor \& Francis, 2001.

LeCourt, Donna. Identity Matters: Schooling the Student Body in Academic Discourse. New York: SUNY Press, 2004.

Oser, Fritz, and Paul Gmünder. Religious Judgment: A Developmental Perspective. Birmingham, AL: Religious Education Press, 1991.

Reisman, Avishag. "Reading Like a Historian: A Document-Based History Curriculum Intervention in Urban High Schools." Cognition and Instruction 30, no. 1 (2012), 86-112.

Rogoff, Barbara. Apprenticeship in Thinking: Cognitive Development in Social Context. Oxford:

Oxford University Press, 1990.

Vygotsky, L. S. Mind and Society: The Development of Higher Mental Processes. Cambridge, MA: Harvard University Press, 1978.

Wineburg, Sam. "Reading Abraham Lincoln: An Expert/Expert Study in the Interpretation of Historical Texts.” Cognitive Science 22, no. 3 (1998), 319-46.

Wineburg, Sam, and Abby Reisman. "Disciplinary Literacy in History." Journal of Adolescent \& Adult Literacy 58, no. 8 (2015), 636-39.

Wortham, Stanton. Learning Identity: The Joint Emergence of Social Identification and Academic Learning. Cambridge: Cambridge University Press, 2006.

Yovel, Yirmiyahu. Spinoza and Other Heretics: The Marrano of Reason. Princeton, NJ: Princeton University Press, 1991. 